\title{
RESEARCH
}

Open Access

\section{Linkage of microbial living communities and residues to soil organic carbon accumulation along a forest restoration gradient in southern China}

Shuo Zhang ${ }^{1,2,3+}$, Qi Deng ${ }^{1 \dagger}$, Ying-Ping Wang ${ }^{4}$, Ji Chen ${ }^{3,5,6}$, Mengxiao Y ${ }^{1}$, Xi Fang ${ }^{7}$, Hongbo He ${ }^{8}$, Jinlei Chen ${ }^{7}$, Pingping $\mathrm{Xu}^{1,2}$, Shenhua Wang ${ }^{1,2}$ and Junhua Yan ${ }^{1 *}$

\begin{abstract}
Background: Forest restoration has been considered an effective method to increase soil organic carbon (SOC), whereas it remains unclear whether long-term forest restoration will continuously increase SOC. Such large uncertainties may be mainly due to the limited knowledge on how soil microorganisms will contribute to SOC accumulation over time.

Methods: We simultaneously documented SOC, total phospholipid fatty acids (PLFAs), and amino sugars (AS) content across a forest restoration gradient with average stand ages of 14, 49, 70, and > 90 years in southern China.

Results: The SOC and AS continuously increased with stand age. The ratio of fungal PLFAs to bacterial PLFAs showed no change with stand age, while the ratio of fungal AS to bacterial AS significantly increased. The total microbial residue-carbon (AS-C) accounted for $0.95-1.66 \%$ in SOC across all forest restoration stages, with significantly higher in fungal residue-C $(0.68-1.19 \%)$ than bacterial residue-C $(0.05-0.11 \%)$. Furthermore, the contribution of total AS-C to SOC was positively correlated with clay content at $0-10 \mathrm{~cm}$ soil layer but negatively related to clay content at $10-20 \mathrm{~cm}$ soil layer.
\end{abstract}

Conclusions: These findings highlight the significant contribution of AS-C to SOC accumulation along forest restoration stages, with divergent contributions from fungal residues and bacterial residues. Soil clay content with stand age significantly affects the divergent contributions of AS-C to SOC at two different soil layers.

Keywords: Soil carbon stock, Microbial biomass, Microbial residues, Forest restoration, Soil clay content, Soil layer

\footnotetext{
* Correspondence: jhyan@scib.ac.cn

†'Shuo Zhang and Qi Deng contributed equally to this work and should be considered as co-first authors.

'Key Laboratory of Vegetation Restoration and Management of Degraded Ecosystems, South China Botanical Garden, Chinese Academy of Sciences, 510650 Guangzhou, China

Full list of author information is available at the end of the article
}

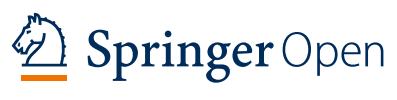

(c) The Author(s). 2021 Open Access This article is licensed under a Creative Commons Attribution 4.0 International License, which permits use, sharing, adaptation, distribution and reproduction in any medium or format, as long as you give appropriate credit to the original author(s) and the source, provide a link to the Creative Commons licence, and indicate if changes were made. The images or other third party material in this article are included in the article's Creative Commons licence, unless indicated otherwise in a credit line to the material. If material is not included in the article's Creative Commons licence and your intended use is not permitted by statutory regulation or exceeds the permitted use, you will need to obtain permission directly from the copyright holder. To view a copy of this licence, visit http://creativecommons.org/licenses/by/4.0/. 


\section{Background}

Forest restoration or reforestation is considered an effective land-based climate mitigation strategy through carbon $(\mathrm{C})$ sequestration in both plant biomass and soil (Lal 2003; Laganière et al. 2010). Many countries, especially China, have implemented national programs to preserve and expand forests, which have substantially contributed to Earth's greening in the past 20 years (Chen et al. 2019). With the establishment of trees, plant biomass $\mathrm{C}$ of a restored forest can reach a similar amount to the previously undisturbed forest within several decades (Farley et al. 2004; Nave et al. 2013; Wang et al. 2017). However, the restoration of soil $C$ to the level of undisturbed forests usually takes much longer times. Furthermore, the impact of forest restoration on soil $\mathrm{C}$ storage is more variable than $\mathrm{C}$ storage in plant biomass, and the key underlying mechanisms for those differential responses are still unclear (Dou et al. 2013; Zhang et al. 2019; Xiong et al. 2020). Therefore, our knowledge is very limited in accurately predicting the $C$ sequestration potential of restored forests (Wieder et al. 2018).

Change of soil $\mathrm{C}$ pool with forest restoration depends on the balance between plant- and microbial-derived $\mathrm{C}$ inputs and outputs processes (Jastrow et al. 2007). However, recent work suggests that microorganisms can directly promote soil organic $\mathrm{C}$ (SOC) formation through the selective retention of anabolic byproducts, especially microbial cells and residues, via an in vivo turnover pathway (Liang et al. 2017). The fraction of soil C derived from microbial residues can be about 40 times larger than the living microbial biomass $C$, and even larger than $50 \%$ of total SOC in some regions (Liang et al. 2019). Amino sugars (AS) are the key compounds of microbial cell walls and primarily occur as microbial residues (Kallenbach et al. 2016). Amino sugars are stable against fluctuations in living microbial biomass size, providing a time-integrated indicator of microbial contributions to soil C storage (Liang et al. 2017). Three prominent AS in the soil are glucosamine (GluN), galactosamine (GalN), and muramic acid (MurA). Among them, GluN is more abundant in fungal than bacterial cell walls, while MurA is exclusively originated from bacteria, and GalN is an essential component of extracellular polymeric substances in the soil (Amelung et al. 2001b). A recent study in northern China found that not only living microbial biomass (represent by phospholipid fatty acids, PLFAs) but also microbial residues (represent by amino sugars, AS) consistently increased with forest restoration (Shao et al. 2019). Therefore, microbial metabolism may play an increasingly important role in SOC sequestration following forest restoration (Kiem and Kögel-Knabner 2003; Ma et al. 2018; Chen et al. 2020b). Meanwhile, the function of fungi and bacteria in $\mathrm{C}$ sequestration may be varied due to the different substrate utilization strategies (Rinnan and Bååth 2009). Specifically, Xu et al. (2019) found that fungi are more able to utilize the recalcitrant substrates in soil, while Koranda et al. (2014) found that bacteria are more favorable in utilizing available substrates. Furthermore, Liang et al. (2019) found that the AS retention patterns in soil varied between fungi and bacteria. Consequently, a better understanding of different AS and their contribution to SOC would profoundly improve the model projection of soil $\mathrm{C}$ sequestration with the implementation of forest restoration.

Forests in southern China account for about one-third of the total forest area in China (Zhou et al. 2006; Zhang et al. 2013). Meanwhile, recent satellite data revealed that forest restoration or reforestation in southern China dominated the greening trend in China over the last three decades (Chen et al. 2019). Unlike northern China, southern China has a relatively warm and moist climate, favoring microbial proliferation and rapid $\mathrm{C}$ turnover (Yang et al. 2020). As a result, high-quality (low C:N) broadleaved litter in the southern forest is more easily decomposed by microorganisms than the coniferous litter in the northern forest. Furthermore, soils in southern China are rich in clay and reactive metal oxides (e.g., iron and aluminum) (Xu et al. 2013), which may inhibit microbial activity through the formation of organomineral complexes that can protect SOC from microbial attack (Six et al. 2002). These factors influence the change of PLFAs and their metabolism may also have various effects on the accumulation of AS in soil following forest restoration. For instance, microbial-derived relatively low molecular weight residue- $\mathrm{C}$ is readily adsorbed by soil clay (Ni et al. 2020). Therefore, high soil clay content in subtropical forests may favor the retention of AS and stabilization of SOC. However, the contribution of AS-derived $\mathrm{C}$ (AS-C) to SOC and its underlying mechanisms following forest restoration in southern China are understudied.

The objectives of this study were to explore how the contribution of PLFAs and AS-C to SOC, and its influencing factors during the forest restoration processes. Here, we substituted space for time by selecting forests across a restoration gradient with average stand ages of 14, 49, 70, and > 90 years in Changsha County, southern China. Soil samples were collected from each of these four stages at $0-10$ and $10-20 \mathrm{~cm}$ soil layers. We measured both PLFAs and AS. Our null hypothesis is that SOC, PLFAs and AS will increase due to the increasing rate of plant residue inputs to soil following forest restoration. In addition, we hypothesized that the contribution of AS-C to SOC increased with time after forest restoration. Three research questions motivated our study: (1) whether PLFAs, AS and SOC consistently increased following forest restoration; (2) how the retention patterns 
in soil between fungal and bacterial residues varied across the forest gradients; and (3) what factors controlled the change in PLFAs and the contribution of AS-C to SOC.

\section{Methods}

\section{Site description}

The study was conducted at Changsha County, Hunan Province, southern China $\left(113^{\circ} 17^{\prime}-113^{\circ} 27^{\prime}\right.$ E, $28^{\circ} 23^{\prime}-$ $\left.28^{\circ} 24^{\prime} \mathrm{N}\right)$. The terrains generally are low-hilly landforms with an altitude of 100 to $550 \mathrm{~m}$, and the slope is between $20^{\circ}$ and $30^{\circ}$. The regional climate is a typical monsoon climate. The mean annual temperature is $16.5^{\circ} \mathrm{C}$, with the warmest month in July $\left(30.7^{\circ} \mathrm{C}\right)$ and the coldest month in January $\left(6.4{ }^{\circ} \mathrm{C}\right.$ ) (Ouyang et al. 2016). The mean annual precipitation is about $1,500 \mathrm{~mm}$ with most rainfall occurring between April and August (Zhu et al. 2016). The soil is classified as Acrisol according to World Reference Base for Soil Resources that developed from slate and shale parent rock (IUSS Working Group WRB 2007).

The climax vegetation of the region is subtropical evergreen broadleaved forests. A range of secondary forests following different restoration stages are found in this region with sporadic primary forests due to the harvesting and natural disturbances. Based on species composition, recovery time, and dominant tree species $(\mathrm{Gu}$ et al. 2019; Chen et al. 2020a), the restoration can be divided into four stages. These forests were regenerated naturally without any tree planting. In this study, four adjacent vegetation communities, with basically similar slope and soil parent materials, were selected to represent a vegetation restoration gradient (using the spacefor-time substitution method). The details of the restoration stages are as follows:

(1) Shrub forests (hereinafter referred to as F14). The native evergreen broadleaved forests were cleared and prescribed-burnt in 1965, then reforested with
Cunninghamia lanceolata in 1966. The plantations were clear-cut in 1989 and logged every 3 to 5 years until 2004, then left undisturbed. The community was dominated by shrubs;

(2) Coniferous and broadleaved mixed forests (hereinafter referred to as F49). The native evergreen broadleaved forests were clear-cut in the early $1970 \mathrm{~s}$, then naturally recovered for nearly 50 years, and formed coniferous and broadleaved mixed forests;

(3) Evergreen broadleaved forests (hereinafter referred to as F70). The native evergreen broadleaved forests were protected by residents for many years, and the stand ages are about 70 years;

(4) Old-growth forests (hereinafter referred to as UF). The native evergreen broadleaved forests were well protected without human disturbances. The stand ages are more than 90 years.

\section{Soil sampling}

In November 2019, 6 plots $(20 \mathrm{~m} \times 20 \mathrm{~m})$ were randomly established within each restoration stage (F14, F49, F70, and UF) to avoid any possible pseudoreplicates. There were in total 24 selected plots across the four different restoration stages. Table 1 includes the general characteristics of the four forest restoration stages. Soil samples were collected with similar slopes (about $20^{\circ}$ ) and aspects (northwest) from the depth of $0-10 \mathrm{~cm}$ (herein defined as topsoil) and $10-20 \mathrm{~cm}$ (herein defined as subsoil) in each plot, respectively. After removing surface litter, 10 core samples were collected using a stainless-steel corer ( $5 \mathrm{~cm}$ diameter) along an S-shape pattern from each soil layer within each plot. The core samples were pooled and homogenized into a single sample. A total of 48 soil samples were collected, representing the 4 forest restoration stages $\times 6$ plots $\times 2$ soil layers. Fresh soils were placed in the Ziplocked bags and transported to the laboratory within $12 \mathrm{~h}$ of

Table 1 General characteristics of the four forest restoration stages

\begin{tabular}{|c|c|c|c|c|}
\hline Restoration stage & Restoration year & Dominant species & Elevation $(\mathrm{m})$ & AGB $\left(\mathrm{kg} \cdot \mathrm{ha}^{-1}\right)$ \\
\hline$\overline{\text { F14 }}$ & $14-16$ & $\begin{array}{l}\text { Loropetalum chinensis, } \\
\text { Cunninghamia lanceolata, } \\
\text { Quercus fabri }\end{array}$ & $120-135$ & $15695.79 \pm 3377.31^{b}$ \\
\hline F49 & $49-50$ & $\begin{array}{l}\text { Pinus massoniana, } \\
\text { Lithocarpus glaber, } \\
\text { Loropetalum chinensis }\end{array}$ & $135-160$ & $107684.94 \pm 5452.03^{\mathrm{a}}$ \\
\hline F70 & $\sim 70$ & $\begin{array}{l}\text { Lithocarpus glaber, } \\
\text { Choerospondias axillaris, } \\
\text { Cyclobalanopsis glauca }\end{array}$ & $85-99$ & $114287.05 \pm 13889.07^{\circ}$ \\
\hline UF & Old-growth forest & $\begin{array}{l}\text { Lithocarpus glaber, } \\
\text { Cleyera japonica, } \\
\text { Cyclobalanopsis glauca }\end{array}$ & $200-260$ & $120695.16 \pm 11552.85^{\circ}$ \\
\hline
\end{tabular}

Different letters indicate significant differences between the four forests at the $P<0.05$ level. Values represent means \pm SE $(n=6)$. The F14, F49, F70, and UF refer to the respective restoration stage, the same below. Abbreviations: $A G B$ above-ground biomass 
collection. Each soil sample was divided into 3 subsamples. All the subsamples were sieved through a $2-\mathrm{mm}$ sieve to remove stones and coarse roots. The subsamples for physic-chemical analysis were air-dried for 30 days, then ground and passed through a $0.15-\mathrm{mm}$ sieve. The other subsamples for analysis of PLFAs were stored at 4 $-{ }^{\circ} \mathrm{C}$ and were completed within one month.

\section{Soil properties analysis}

The total carbon (TC) content of soil was measured with an elemental analyzer (Vario MAX, Elementar, Germany). Because soils are acidic (Table 2), the SOC content was equated to TC content. Soil $\mathrm{pH}$ was measured in the water and $1 \mathrm{~mol} \cdot \mathrm{L}^{-1} \mathrm{KCL}$ (1:2.5 soil: solution) using a pH meter (Five Easy Plus ${ }^{\mathrm{Tw}}$ FP20-Meter, Mettler Toledo, Switzerland). Soil clay (particle size $<2 \mu \mathrm{m}$ ), silt (particle size $2-50 \mu \mathrm{m}$ ), and sand (particle size $50-2000 \mu \mathrm{m}$ ) contents were measured using laser diffraction (MasterSizer 2000, Malvern Corporation). Soil bulk density (BD) was measured gravimetrically in triplicate for generic horizons using the cutting-ring method. SOC stock was calculated as: SOC stock $\left(\mathrm{Mg} \mathrm{C}_{\mathrm{hat}}{ }^{-1}\right)=\mathrm{SOC}(\%) \times \mathrm{BD}\left(\mathrm{g} \cdot \mathrm{cm}^{-3}\right) \times$ soil depth $(\mathrm{cm}) \times(1-\delta)$, and $\delta$ is the mass percentage of fragments and stone $(>2 \mathrm{~mm})$.

\section{Microbial PLFAs analysis}

Microbial PLFAs were measured following a protocol by Frostegård et al. (1993). Briefly, PLFAs were extracted from 2-g freeze-dried and homogenized soil using a specific ratio (1:2:0.8 by vol.; $\mathrm{pH}$ 7.4) in a single-phase mixture of chloroform/methanol/phosphate buffer. The PLFA extractions were analyzed using a gas chromatograph equipped with a flame-ionization detector (Agilent 6890, Agilent Technologies, Palo Alto, CA, USA). The content of each fatty acid was expressed as nmol per $\mathrm{g}$ of dry soil $\left(\mathrm{nmol} \cdot \mathrm{g}^{-1}\right)$ by the 19:0 internal standard contents (Vestal and White 1989). The total PLFAs content was calculated by summing up all fatty acids mentioned below ( $C$ atoms numbers $<20$ ). Microbial functional groups were represented by a suit of fatty acids in our study as follows (Frostegård and Bååth 1996; Zelles 1997):

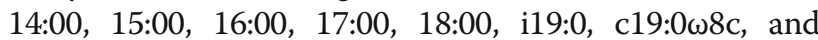
$10 \mathrm{Me} 19: 1 \omega 7 \mathrm{c}$ were used as general bacteria; i14:0, i15:0, a15:0, i16:0, i17:0, a17:0, i18:0, i17:1 $\omega 9$ c for gram-positive bacteria; $16: 1 \omega 7 \mathrm{c}, \mathrm{cy} 17: 0,18: 1 \omega 7,17: 1 \omega 8 \mathrm{c}$, and $10 \mathrm{Me} 17$ : $1 \omega 7 \mathrm{c}$ for gram-negative bacteria; $18: 1 \omega 9 \mathrm{c}, 18: 2 \omega 6 \mathrm{c}$, and $18: 3 \omega 3 \mathrm{c}$ for fungi; $16: 1 \omega 5 \mathrm{c}$ for arbuscular mycorrhizal fungi; 10Me16:0, 10Me17:0 and 10Me18:0 for actinomycete. The ratio of fungal to bacterial PLFAs (F:B) was calculated by dividing the sum of all fungal and bacterial fatty acids separately (Frey et al. 1999; Strickland and Rousk 2010).

\section{Amino sugars analysis}

Amino sugars were analyzed following a method by Zhang and Amelung (1996) with slight modifications. Briefly, $0.5 \mathrm{~g}$ air-dried soil sample $(<2 \mathrm{~mm})$ was hydrolyzed with $10 \mathrm{~mL} 6 \mathrm{~mol} \cdot \mathrm{L}^{-1} \mathrm{HCl}$ at $105^{\circ} \mathrm{C}$ for $8 \mathrm{~h}$ in a closed hydrolysis flask. The internal standard $(100 \mu \mathrm{g}$ myoinositol) was added to the cooling hydrolysate. The filtered hydrolysate was dried at $52{ }^{\circ} \mathrm{C}$ using a rotary evaporator. The dried sample was re-dissolved in the approximately $6 \mathrm{~mL}$ deionized water and adjusted $\mathrm{pH}$ to 6.6-6.8 with $1 \mathrm{~mol} \cdot \mathrm{L}^{-1} \mathrm{KOH}$. Then, the sample was

Table 2 Soil and microbial properties between the four forest restoration stages

\begin{tabular}{|c|c|c|c|c|c|c|c|c|}
\hline \multirow[b]{3}{*}{ Soil layer } & \multicolumn{8}{|c|}{ Forest restoration stages } \\
\hline & \multicolumn{2}{|l|}{ F14 } & \multicolumn{2}{|l|}{ F49 } & \multicolumn{2}{|l|}{ F70 } & \multicolumn{2}{|l|}{ UF } \\
\hline & Topsoil & Subsoil & Topsoil & Subsoil & Topsoil & Subsoil & Topsoil & Subsoil \\
\hline \multicolumn{9}{|l|}{ Soil properties } \\
\hline $\mathrm{pH}$ & $4.75 \pm 0.07^{\mathrm{A}}$ & $4.78 \pm 0.06^{\mathrm{a}}$ & $4.43 \pm 0.04^{C}$ & $4.50 \pm 0.03^{b}$ & $4.59 \pm 0.03^{B}$ & $4.57 \pm 0.01^{\mathrm{b}}$ & $4.50 \pm 0.04^{B C}$ & $4.50 \pm 0.04^{b}$ \\
\hline $\mathrm{BD}\left(\mathrm{g} \cdot \mathrm{cm}^{-3}\right)$ & $1.35 \pm 0.01^{\mathrm{A}}$ & $1.47 \pm 0.02^{\mathrm{a}}$ & $1.11 \pm 0.01^{c}$ & $1.42 \pm 0.00^{\mathrm{a}}$ & $1.27 \pm 0.03^{B}$ & $1.29 \pm 0.02^{b}$ & $1.26 \pm 0.01^{B}$ & $1.43 \pm 0.01^{\mathrm{a}}$ \\
\hline Sand (\%) & $77.69 \pm 0.35^{\mathrm{A}}$ & $70.62 \pm 0.45^{a}$ & $24.08 \pm 0.94^{C}$ & $19.78 \pm 0.41^{c}$ & $16.85 \pm 0.66^{\mathrm{D}}$ & $16.23 \pm 1.14^{d}$ & $43.93 \pm 0.87^{B}$ & $45.88 \pm 0.97^{b}$ \\
\hline Silt (\%) & $18.17 \pm 0.31^{\mathrm{A}}$ & $23.85 \pm 0.18^{c}$ & $61.82 \pm 1.16^{\mathrm{B}}$ & $65.38 \pm 0.44^{a}$ & $66.88 \pm 0.69^{A}$ & $66.49 \pm 0.87^{a}$ & $44.75 \pm 0.71^{C}$ & $43.67 \pm 0.97^{b}$ \\
\hline Clay (\%) & $4.14 \pm 0.29^{C}$ & $5.53 \pm 0.30^{d}$ & $14.10 \pm 0.84^{\mathrm{A}}$ & $14.84 \pm 0.26^{b}$ & $16.27 \pm 0.53^{\mathrm{A}}$ & $17.28 \pm 0.55^{\mathrm{a}}$ & $11.32 \pm 0.72^{B}$ & $10.45 \pm 0.24^{c}$ \\
\hline \multicolumn{9}{|c|}{ Soil microbial PLFAs $\left(\mathrm{nmol} \cdot \mathrm{g}^{-1}\right)$} \\
\hline Bacterial PLFA & $6.44 \pm 0.32^{B}$ & $4.10 \pm 0.17^{b}$ & $3.56 \pm 0.39^{C}$ & $2.42 \pm 0.27^{b}$ & $8.75 \pm 0.52^{\mathrm{A}}$ & $2.98 \pm 0.11^{b}$ & $9.24 \pm 0.72^{\mathrm{A}}$ & $11.46 \pm 1.07^{\mathrm{a}}$ \\
\hline Fungal PLFA & $0.60 \pm 0.03^{B C}$ & $0.49 \pm 0.05^{b}$ & $0.42 \pm 0.07^{c}$ & $0.28 \pm 0.06^{b}$ & $0.97 \pm 0.04^{\mathrm{A}}$ & $0.36 \pm 0.02^{b}$ & $0.81 \pm 0.07^{A B}$ & $1.42 \pm 0.14^{\mathrm{a}}$ \\
\hline \multicolumn{9}{|c|}{ Soil amino sugar parameters $\left(\mathrm{mg} \cdot \mathrm{kg}^{-1}\right)$} \\
\hline GluN & $316.84 \pm 29.77^{D}$ & $116.65 \pm 10.93^{d}$ & $415.66 \pm 7.28^{c}$ & $298.97 \pm 12.31^{c}$ & $502.64 \pm 10.01^{B}$ & $320.89 \pm 3.82^{b}$ & $598.21 \pm 5.09^{A}$ & $336.84 \pm 7.53^{a}$ \\
\hline MurA & $27.83 \pm 4.17$ & $12.83 \pm 1.75^{b}$ & $27.95 \pm 1.39$ & $21.38 \pm 1.24^{a}$ & $26.03 \pm 2.14$ & $20.87 \pm 1.04^{\mathrm{a}}$ & $27.76 \pm 3.50$ & $20.31 \pm 1.64^{\mathrm{a}}$ \\
\hline GalN & $92.86 \pm 17.68^{C}$ & $33.37 \pm 3.38^{c}$ & $141.06 \pm 4.95^{\mathrm{B}}$ & $104.14 \pm 5.57^{b}$ & $152.56 \pm 1.63^{\mathrm{B}}$ & $110.10 \pm 2.10^{b}$ & $176.67 \pm 3.77^{\mathrm{A}}$ & $133.24 \pm 3.56^{a}$ \\
\hline
\end{tabular}

Different uppercase and lowercase letters indicate significant differences in topsoil and subsoil between the four restoration stages at the $P<0.05$ level. Values are means \pm SE $(n=6)$. Abbreviations: BD bulk density; GalN galactosamine; GluN glucosamine; MurA muramic acid 
centrifuged for $10 \mathrm{~min}$ at $935 \mathrm{~g}$ and the supernatant was re-rotating evaporation at $52{ }^{\circ} \mathrm{C}$. After drying, $3 \mathrm{~mL}$ absolute methanol was added to dissolve the residue. The supernatant was transferred to a conical reaction vial and dried by $\mathrm{N}_{2}$ gas at $45{ }^{\circ} \mathrm{C}$. The dried residue was added with $1 \mathrm{~mL}$ deionized water and $100 \mu \mathrm{L} \mathrm{N}$ methylglucamine, then freeze-drying. After drying, the residue was dissolved with a $300-\mu \mathrm{L}$ derivatization reagent, which contains $32 \mathrm{mg} \cdot \mathrm{mL}^{-1}$ hydroxylamine hydrochloride and $40 \mathrm{mg} \cdot \mathrm{mL}^{-1}$ 4-dimethylaminopyridine in pyridine-methanol $(4: 1 \mathrm{v} / \mathrm{v})$. The sample solution was fully mixed by swirling and heating at 75$80{ }^{\circ} \mathrm{C}$ for $35 \mathrm{~min}$. After cooling, the derivative was acetylated with $1 \mathrm{~mL}$ acetic anhydride and reheated at 75$80{ }^{\circ} \mathrm{C}$ for $25 \mathrm{~min}$, then mixed with $1.5 \mathrm{~mL}$ dichloromethane. Excessive derivatization reagent (residual anhydride) was removed by extracting with $1 \mathrm{~mol} \cdot \mathrm{L}^{-1} \mathrm{HCL}$ and deionized water. The remaining dichloromethane phase contains AS derivative was dried by $\mathrm{N}_{2}$ gas at $45{ }^{\circ} \mathrm{C}$. Finally, the AS derivatives were redissolved with $200 \mu \mathrm{L}$ ethyl acetate-hexane (1:1) and separated on a gas chromatograph (HP 6890, Agilent, USA) equipped with an HP-5 fused silica column $(30 \mathrm{~m} \times 0.25 \mathrm{~mm} \times 0.25 \mu \mathrm{m})$. The individual AS (glucosamine, galactosamine, and muramic acid) derivatives were separated by referencing the retention times of authentic standards. The total AS content was calculated as the sum of the individual AS (Amelung et al. 2001b). The fungal residue-C (GluN-C), bacterial residue-C (MurA-C), and GalN-C were using the following equations (Engelking et al. 2007): GluN$\mathrm{C}=72 \times$ GluN/179.2, GalN-C $=72 \times$ GalN/179.2, and MurA-C $=108 \times$ MurA/251.23. The total AS-C was estimated as the sum of GluN-C, GalN-C and MurA-C. The proportion of AS-C in SOC content was used to describe the relative contribution of AS-C to SOC (AS-C/ SOC) (Liang et al. 2019). The ratio of GluN to MurA (GluN:MurA) was calculated to differentiate fungal and bacterial residues in soil (Zhang et al. 1998; Amelung et al. 2001a; Six et al. 2006).

\section{Statistical analysis}

The data were first tested for normal distribution and homogeneity of variance, and no data were natural logtransformed. After confirming the data followed a normal distribution, a one-way analysis of variance (ANOVA) with Tukey's multiple comparison test (HSD) was used to determine how SOC, microbial PLFAs, and AS changed between forest restoration stages and soil layers. In addition, a generalized linear model (GLM) with normal distribution was applied to evaluate the relationship of SOC, PLFAs, AS, and AS-C/SOC to plant and soil properties. All statistical analyses were carried out with IBM SPSS Version 24.0 (IBM Corp., New York, USA) statistical software. Figures were plotted with
SigmaPlot 14.0 software (Systat Software Inc., San Jose, USA).

\section{Results}

Variation of soil properties following forest restoration

The SOC content in both soil layers generally increased following forest restoration (Fig. $1, P<0.05$ ), with the lowest value in F14 (10.65 and $6.96 \mathrm{~g} \cdot \mathrm{kg}^{-1}$ in topsoil and subsoil, respectively). There was no significant difference in SOC content between F70 and UF in topsoil. Similarly, there was no difference in SOC content between F49 and F70 in subsoil. The SOC stock increased with time since forest restoration (Fig. $1, P<0.05$ ), with the lowest value in F14 $\left(24.60 \mathrm{Mg} \mathrm{C} \cdot \mathrm{ha}^{-1}\right)$ and the highest value in UF (51.12 $\left.\mathrm{Mg} \mathrm{C}_{\mathrm{ha}}{ }^{-1}\right)$.

Soil $\mathrm{pH}$, soil BD, and soil clay content changed with soil layer and forest restoration stage (Table $2, P<0.05$ ). The soil was consistently acidic in both soil layers, with the lowest value in F49 (4.43 and 4.50 in topsoil and subsoil, respectively) and the highest value in F14 (4.75 and 4.78 in topsoil and subsoil, respectively). Soil BD in topsoil significantly decreased from F14 $\left(1.35 \mathrm{~g} \cdot \mathrm{cm}^{-3}\right)$ to F49 $\left(1.11 \mathrm{~g} \cdot \mathrm{cm}^{-3}\right)$ and then increased with forest restoration. In the subsoil, the BD in the F70 $\left(1.29 \mathrm{~g} \cdot \mathrm{cm}^{-3}\right)$ was significantly lower than it was in the other three restoration stages (Table 2, $P<0.05$ ). Soil clay content showed a trend of initial increase, then decline in both soil layers following forest restoration (Table 2), with the lowest value in F14 (4.14 and $5.53 \%$ in topsoil and subsoil, respectively) and the highest value in F70 (16.27 and $17.28 \%$ in topsoil and subsoil, respectively).

\section{Variation of soil living microbial biomass following forest restoration}

Soil living microbial biomass (represented as PLFAs) changed significantly between forest restoration stages. Total PLFAs showed a general trend of an initial decrease and then increase (Fig. 2a, $P<0.05$ ) in topsoil, with the lowest value in F49 $\left(4.41 \mathrm{nmol} \cdot \mathrm{g}^{-1}\right)$ and the highest value in UF $\left(11.54 \mathrm{nmol} \cdot \mathrm{g}^{-1}\right)$. While in subsoil, total PLFAs were significantly higher in UF (14.53 $\mathrm{nmol} \cdot \mathrm{g}^{-1}$ ) than in the other three restoration stages, and no significant difference was found between these three stages. The F:B ratio showed no significant differences between the different forest restoration stages in both soil layers (Fig. 2b). The content of different individual PLFAs in soil between the four forest restoration stages was listed in Table S1.

\section{Variation of soil microbial residues following forest restoration}

We found that total AS contents increased following forest restoration in both soil layers (Fig. 3a, $P<0.05$ ), with the lowest value in F14 (437.53 and $162.84 \mathrm{mg} \cdot \mathrm{kg}^{-1}$ in 


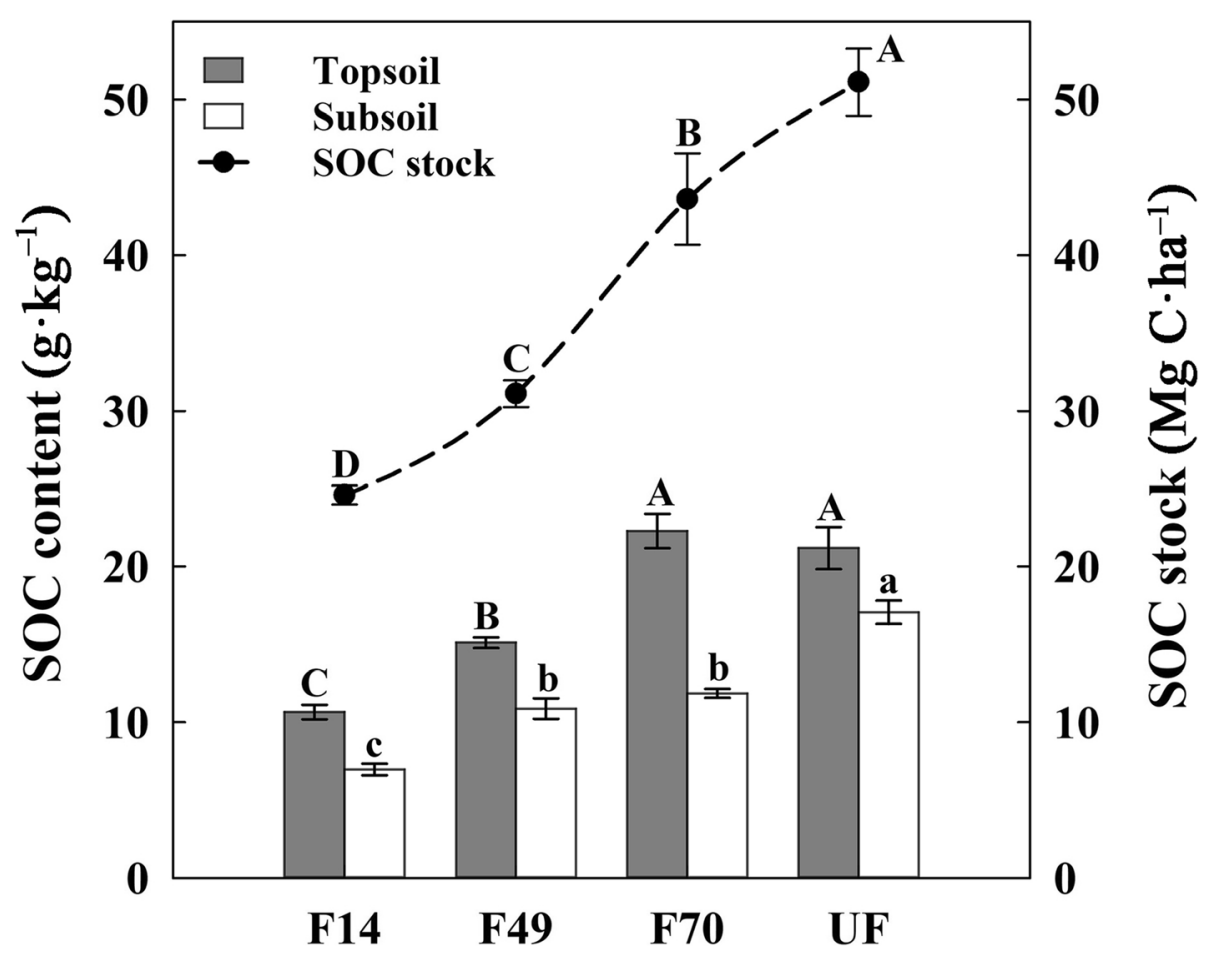

Fig. 1 Variations of SOC stock (dotted line) and SOC contents (bar) following forest restoration. Different uppercase and lowercase letters indicate significant differences in topsoil (grey bar) and subsoil (white bar) between the four restoration stages at the $P<0.05$ level. Symbols and bars represent means $\pm \operatorname{SE}(n=6)$

topsoil and subsoil, respectively) and the highest value in UF (802.63 and $490.40 \mathrm{mg} \cdot \mathrm{kg}^{-1}$ in topsoil and subsoil, respectively). The GluN:MurA ratio increased following forest restoration at both soil layers (Fig. $3 \mathrm{~b}, P<0.05$ ), with the lowest value in F14 (11.66 and 9.16 in topsoil and subsoil, respectively) and the highest value in UF (21.85 and 16.68 in topsoil and subsoil, respectively).

\section{Contribution of microbial residue-C to SOC following forest restoration}

The total microbial residue $\mathrm{C}$ accounted for $0.95-1.66 \%$ in SOC across all forest restoration stages (Fig. 4). In topsoil, the microbial residue- $\mathrm{C}$ in $\mathrm{SOC}$ (AS-C/SOC) was significantly lower in F70 (1.23\%) than in other forests. In subsoil, the AS-C/SOC was significantly lower in

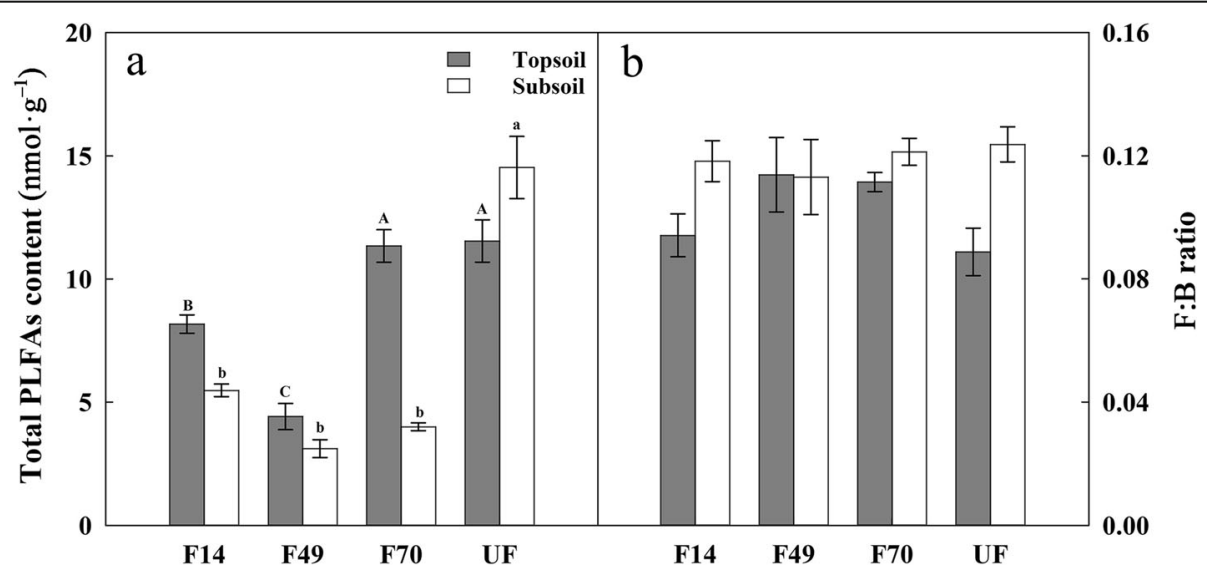

Fig. 2 Variations of the total PLFAs content (panel A), the ratio of fungal to bacterial PLFAs (F:B, panel B) following forest restoration. Different uppercase and lowercase letters indicate significant differences in topsoil (grey bar) or subsoil (white bar) between the four restoration stages at the $P<0.05$ level. Bars represent means $\pm \mathrm{SE}(n=6)$ 


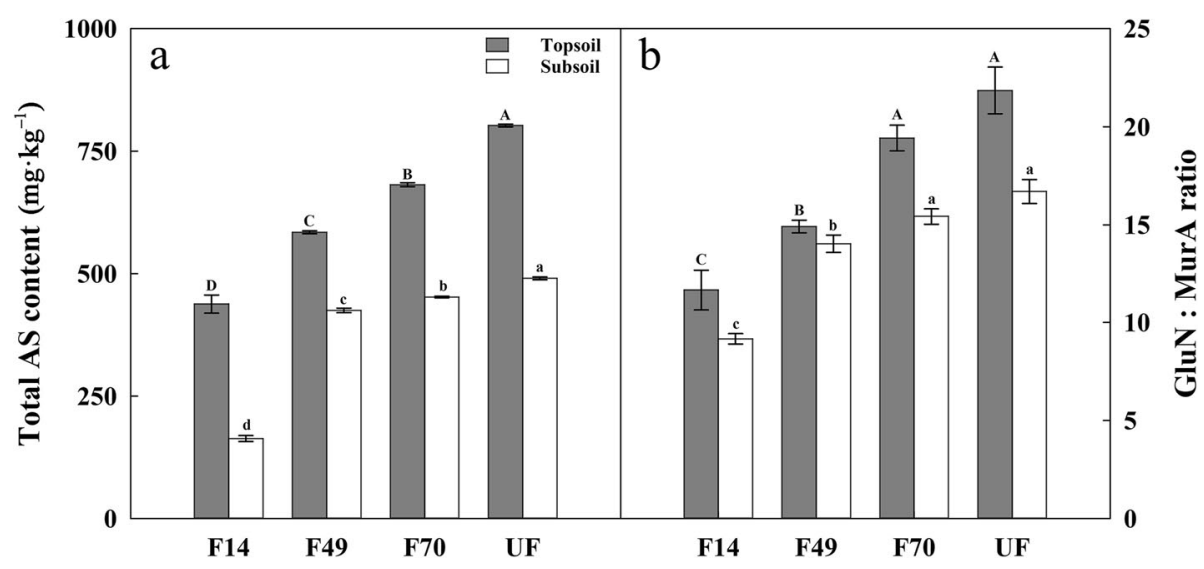

Fig. 3 Variations of total amino sugars content (AS, panel A), and the ratio of fungal to bacterial residues in soil (GluN:MurA, panel B) following forest restoration. Different uppercase and lowercase letters indicate significant differences in topsoil (grey bar) and subsoil (white bar) between the four restoration stages at the $P<0.05$ level. Bars represent means \pm SE $(n=6)$

F14 $(0.95 \%)$ and UF $(1.16 \%)$ than in other forests. The contribution of fungal residue-C in SOC (GluN-C/SOC) was significantly lower in F70 (0.91\%) and F49 (1.11\%) than in other forests in topsoil, which was significantly lower in F14 (0.68\%) and UF (0.80\%) in subsoil (Fig. 4b, $P<0.05$ ). The bacterial residue-C in SOC (MurA-C) decreased significantly in topsoil following forest restoration $(P<0.05$, Fig. $4 \mathrm{c})$, with the lowest value in F70 $(0.05 \%)$ and the highest value in F14 $(0.11 \%)$. In subsoil, the MurA-C/SOC was significantly lower in UF (0.05\%) than in other forests.

\section{Correlation analysis}

The linear correlation showed that SOC content was positively correlated with AGB in both soil layers and with clay content in topsoil (Fig. 5a, b and $P<0.001$ ). The total AS content was also positively correlated with AGB and clay content in both soil layers (Fig. 5e, $\mathrm{f}$ and $P<0.001)$. However, there was no relationship between total PLFAs and AGB or soil clay content across the forest restoration gradient (Fig. $5 \mathrm{c}, \mathrm{d}$ and $P \geq 0.05$ ). The AS-C/SOC was negatively correlated with clay content in topsoil (Fig. $5 \mathrm{~h}, P<0.001$ ), while it was positively correlated with clay content and AGB in subsoil (Fig. $5 \mathrm{~g}$ and $5 \mathrm{~h}, P<0.001)$.

\section{Discussion}

\section{Changes in SOC, microbial living biomass and residues following forest restoration}

In terrestrial ecosystems, SOC stock depends mainly on the balance between the input and output of $C$ in the soil. With the establishment and growth of trees, forest restoration generally increases the input of plant residues into the soil. At the same time, the input of plant residues and the improvement of soil conditions may also stimulate microbial activity and increase the decomposition of plant residues and soil organic matter. Our study demonstrated that forest restoration significantly increased SOC stock following forest restoration in the Changsha county area of southern China (Fig. 1). This result was consistent with previous studies ( $\mathrm{Lu}$ et al. 2018; Zhang et al. 2019), suggesting that the increased input of plant residues following forest restoration cannot be offset by the increased microbial decomposition. The positive linear relationship between SOC content and AGB observed here supported this view (Fig. 5a). In addition, the increasing vegetation cover and the developing root systems with the forest restoration may reduce loss of soil organic matter from erosion and promote aggregate formation to increase the soil clay content (Sauer et al. 2012; Sun et al. 2019). Meanwhile, the increasing clay content could also enhance SOC accumulation by forming clay-humic complexes and eventually protected SOC from microbial attack (Six et al. 2002). This explanation was supported by the positive linear relationship between SOC and soil clay content as observed in topsoil (Fig. 5b). Previous studies indicated that SOC accumulation might depend on litter quality rather than litter quantity (Zhou et al. 2019). However, in this study, we did not find any significant relationship between SOC and litter $\mathrm{C}: \mathrm{N}$ ratio, probably due to the relatively small variation of litter $\mathrm{C}$ : $\mathrm{N}$ ratio across the four forest sites. Previous studies indicated that soil $\mathrm{C}$ stocks could reach the equivalent level of the undisturbed old-growth forests within about 60 years of restoration in the tropical region (Zhang et al. 2019), while it takes about 120 years in the northern temperate forests (Shao et al. 2019). However, our study sites are located in the subtropical region. Hence we speculate that SOC stock in our restored forests may take no than 120 years to reach the equivalent level of the undisturbed old-growth forests. 


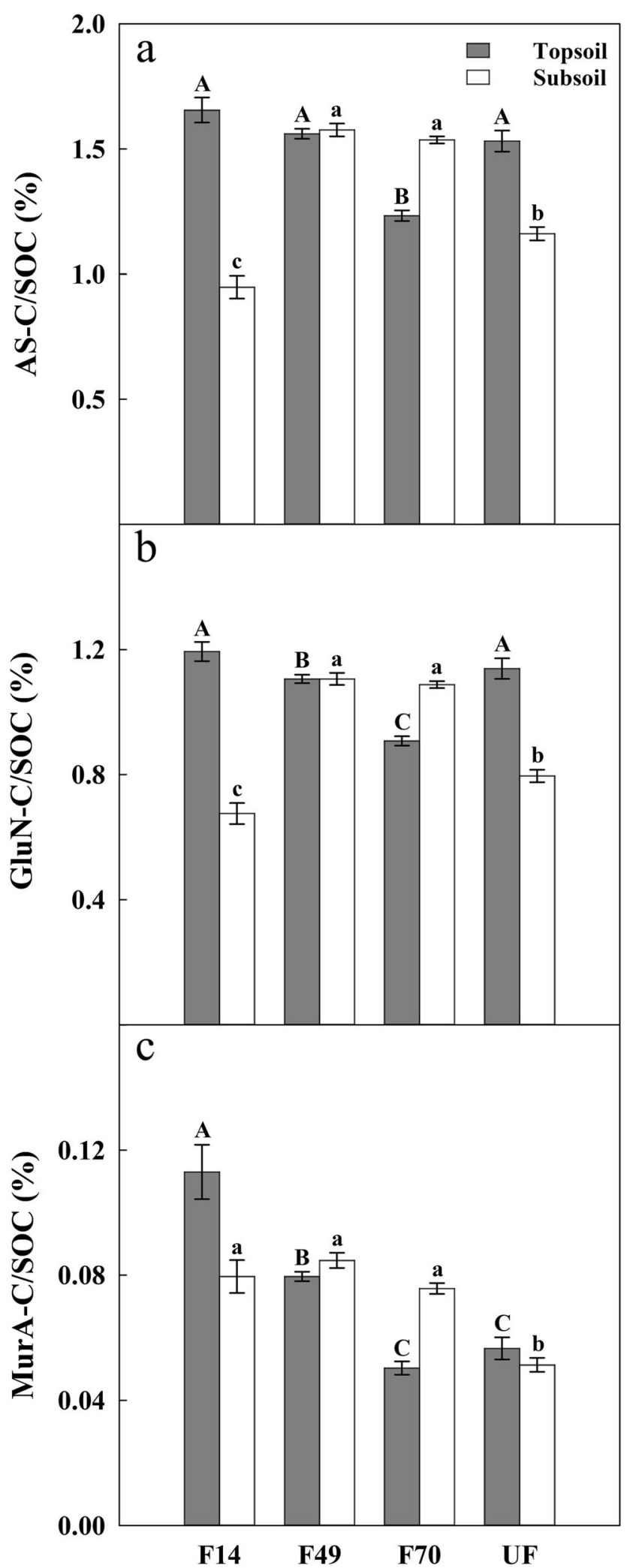

Fig. 4 Variations of total microbial residue-C (AS-C, panel A), fungal residue-C (GluN-C, panel B), and bacterial residue-C (MurA-C, panel C) in SOC following forest restoration. Different uppercase and lowercase letters indicate significant differences in topsoil (grey bar) or subsoil (white bar) between the four restoration stages at the $P<0.05$ level. Bars represent means \pm SE $(n=6)$ 


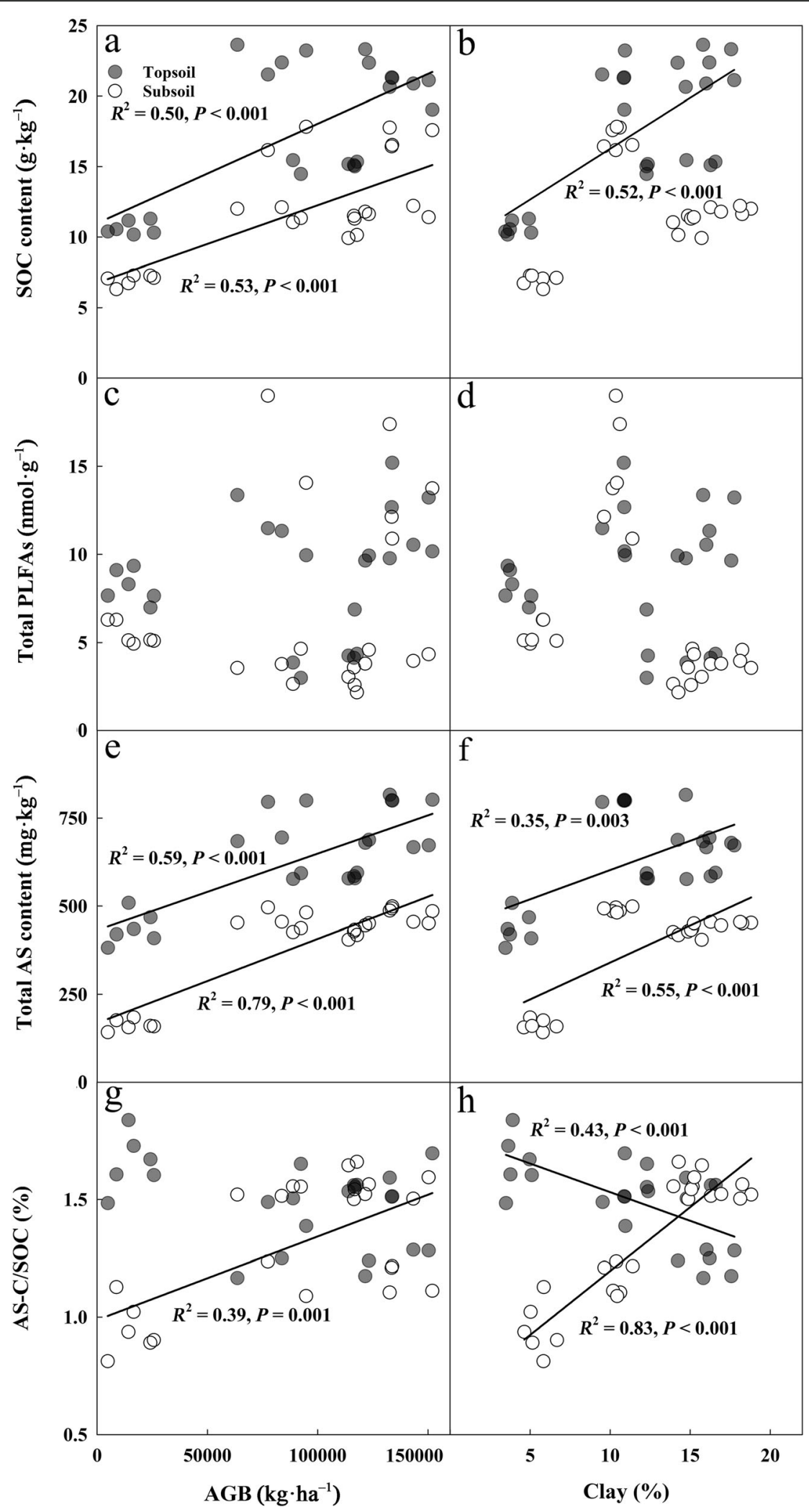

Fig. 5 (See legend on next page.) 
(See figure on previous page.)

Fig. 5 Linear regression of SOC content $(\mathbf{A}-\mathbf{B})$, total PLFAs content $(\mathbf{C}-\mathbf{D})$, total AS content $(\mathbf{E}-\mathbf{F})$ content and its contribution to SOC (G-H) against AGB and soil clay content following forest restoration. Symbols (filled circle) and (open circle) correspond to topsoil and subsoil, respectively. Solid lines depict significant linear relationships, while plots without regression lines are not linearly related $(P \geq 0.05)$. Abbreviations: AGB, above-ground biomass; AS, amino sugar; AS-C/SOC, the contribution of total microbial residue-C to SOC

The change of the PLFAs following forest restoration differed from SOC (Fig. 2a). The PLFAs reflect the instantaneous state of microorganisms, which decompose quickly after cell death (Zelles 1999; Veum et al. 2019). In this study, we did not find any significant relationship of the PLFAs with either AGB or soil clay content (Fig. $5 \mathrm{c}$ and $\mathrm{d}$ ), probably because of the opposing effects of increasing AGB and soil clay content on PLFAs. With forest restoration, the increasing input of plant residues may stimulate microbial proliferation, while the enhanced soil clay content may restrain microbial activity due to the more robust physical protection of $C$ from microbial attack (Lützow et al. 2006; Yu et al. 2019). For example, the PLFAs were reduced by the higher soil clay content in F49, as compared with those in F14 (Fig. 2a).

Unlike the PLFAs, the AS content in soil represents the accumulation of microbial turnover over time. Despite relatively high soil clay content and low PLFAs in F49, the F49 had higher AS content than the F14 (Fig. 3a). In addition, empirical evidence indicates that microbial-derived $C$ generally has relatively low molecular weights, which are readily adsorbed by soil clay, and that a high content of soil clay is conducive to the retention of AS. Consequently, the positive relationships of AS with both AGB and soil clay content following forest restoration were also observed in this study (Fig. 5e and f). However, it is noteworthy that the AGB perks at the F49 and clay content perks at the F70, whereas both SOC and AS continually increased with the highest in UF. Therefore, a high microbial turnover rate might further increase the AS and hence SOC at the UF.

\section{Fungal residues dominate the contribute to SOC following forest restoration}

Soil F:B ratios are highly linked to soil $\mathrm{C}$ accumulation potential (Malik et al. 2016). Due to the different utilization of substrates, the growth and proliferation of bacteria and fungi are different, and may eventually lead to divergent $\mathrm{F}: \mathrm{B}$ ratios in PLFAs and fungi/bacteria derived AS following forest restoration. Our study observed no significant change in F:B ratios across the forest restoration gradient (Fig. 2b), while GluN:MurA ratios significantly increased (Fig. 3b). This was contrary to a previous study in southern China showing that the GluN:MurA significantly decreased with forest succession (Shao et al. 2017). The decreasing GluN:MurA in Shao et al. (2017)'s study suggested a dramatic shift from needle-leaf to broad-leaf during forest succession.
Higher quality of broad-leaf is more generally favored for bacterial proliferation and the production of its residues over fungi than needle-leaf (Bossuyt et al. 2001; Kramer et al. 2012). In our study, however, the litter quality under different restoration stages varied nonsignificantly. Therefore, no significant differences were found in the F:B of PLFAs following forest restoration.

The accumulation of AS depends on not only the production but also the retention. Although the biomass turnover rate is thought to be slower in fungi than in bacteria, fungal biomass often contains high $\mathrm{C}$ content compared to bacteria biomass (Strickland and Rousk 2010). Thus, while the abundances of fungi and bacteria changed similarly following forest restoration, fungi might contribute to more AS production than bacteria. In addition, fungal residues are more decompositionresistant than bacterial counterparts after cell death (Nakas and Klein 1979), thus are likely the preferential retention following forest restoration. Higher fungal abundance has also been related to the higher capacity of $\mathrm{C}$ accumulation and lower turnover rate due to enhanced fungal mediated soil aggregation and/or changes in the physiology of the microbial biomass (Six et al. 2006; Malik et al. 2016). Thus, a continuously increased fungal residues dominance in the forest restoration process is thought to enhance SOC accumulation and stabilization.

\section{Clay content affected the contributions of microbial residue $\mathrm{C}$ to $\mathrm{SOC}$}

The AS is the critical and direct pathway of SOC formation (Liang et al. 2017). In this study, we found a slightly decreasing trend of AS-C/SOC at topsoil following forest restoration (Fig. 4a), which is contrary to a previous study by Shao et al. (2017) in southern China, probably due to the different changing patterns in vegetation communities and litter quality between our study sites. Alternatively, we found that change in soil clay content may have played an essential role in regulating AS-C/ SOC following forest restoration with different mechanisms between the topsoil and subsoil layer.

The topsoil is a hotspot for microbial activity (Xu et al. 2013), as large amounts of plant residues can be assimilated by soil microorganisms (Cotrufo et al. 2015). Therefore, even a small change of microbial activity in topsoil may not only affect the production of AS but also the accumulation of plant residues ( $\mathrm{Ni}$ et al. 2020). The negative relationship between the AS-C/SOC and soil 
clay content as observed in the topsoil in this study (Fig. $5 \mathrm{~h}$ ) probably resulted from the negative effects of increasing soil clay content following forest restoration on the proliferation and the residues production of soil microbes, resulting in more plant residue-derived $\mathrm{C}$ retention in the soil. Furthermore, because of the difference in the ecological preferences of fungi versus bacteria in their habitats, the increased $\mathrm{C}$ availability due to clay adsorption may have more limited bacterial activities than fungal activities (Fomina and Skorochod 2020). The bacterial residues are more readily decomposed than fungal residues (Nakas and Klein 1979). Therefore the contribution of MurA-C/SOC in topsoil decreased significantly following forest restoration while the GluN-C/SOC remained relatively constant (Fig. 4b and $\mathrm{c}$ ).

In contrast to the topsoil, we found that AS-C/SOC was positively correlated with soil clay content in subsoil (Fig. 5 h). The PLFAs in subsoil were relatively lower than that in topsoil (Fig. 2a) due to lower SOC content (Fig. 1), and the direct effect of plant residues was weaker than in the topsoil. We speculate that AS in subsoil was not entirely derived from the counterparts of PLFAs after cell death, but also a large part of them may be derived from the input of topsoil AS via leaching. Collectively, higher clay content in subsoil likely favored the retention of topsoil AS when they moved down to subsoil, because the microbial-derived relatively low molecular weight residue- $C$ is readily adsorbed by microaggregates. In addition, higher clay content would inhibit microbial metabolism in subsoil, resulting in a lower turnover rate of AS. The findings reported in our study were supported by a recent review by $\mathrm{Ni}$ et al. (2020), who found that AS in topsoil was dominantly determined by its production while in subsoil depended on its retention by soil clay content.

\section{Conclusions}

This study stressed the microbially regulated SOC accumulation following forest restoration by using measurements of two biomarkers, PLFAs and AS that represent microbial living biomass and residues, respectively. We found that SOC increased with increasing AGB with time after forest restoration. However, the PLFAs and AS changed differently following the forest restoration. Even though the ratio of fungal PLFAs to bacterial PLFAs showed no change following forest restoration, the ratio of fungal residues to bacterial residues significantly increased. These results suggest that fungal residues may play a more critical role than bacterial residues in SOC accumulation following forest restoration at our study site. In addition, the clay content had a significantly positive effect on the contribution of microbial residue-C to $\mathrm{SOC}$ in the $0-10 \mathrm{~cm}$ soil layer, but a significantly negative effect in the $10-20 \mathrm{~cm}$ soil layer. This result highlights the divergent physical mechanisms in regulating microbial-mediated SOC accumulation at two different soil layers following the forest restoration in subtropical ecosystems. The divergent contribution of microbial residues to soil $\mathrm{C}$ accumulation across a forest restoration gradient in our study is essential for improving forest management practices.

\begin{abstract}
Abbreviations
AGB: Above-ground biomass; AMF: Arbuscular mycorrhizal fungi; AS: Amino sugars; AS-C: Microbial residue-C; AS-C/SOC: The contribution of total microbial residue-C to SOC; BD: Bulk density; C: Carbon; F:B: The ratio of fungal PLFAs to bacterial PLFAs; $\mathrm{G}^{+}$: Gram-positive bacteria; $\mathrm{G}^{-}$: Gramnegative bacteria; GalN: Galactosamine; GluN: Glucosamine; GluN-C: Fungal residue-C; GluN-C/SOC: The contribution of fungal residue-C to SOC; GluN; MurA: The ratio of fungal residues to bacterial residues; MurA: Muramic acid; MurA-C: Bacterial residue-C; MurA-C/SOC: The contribution of bacterial residue-C to SOC; PLFAs: Phospholipid fatty acids; SOC: Soil organic carbon; TC: Total carbon
\end{abstract}

\section{Supplementary Information}

The online version contains supplementary material available at https://doi. org/10.1186/s40663-021-00334-8.

\section{Additional file 1.}

\section{Acknowledgements}

We thank Zhongbing Chang, Yang Chen, Nannan Cao, and Zhiwei Cao for the help with field sampling. We also thank Lingxue Ma, Xiaoying You, Xiaoping Pan, Wei Zhang, and Yi Li for the help with laboratory analysis.

\section{Authors' contributions}

QD and JY conceived and designed the study; SZ analyzed the data, drew the figures and wrote the primary draft; SZ and SW did the measurements; YW and JC revised the draft; MY, PX and JC collected the samples; XF and $\mathrm{HH}$ discussed the draft with SZ. All authors contributed critically to the drafts and gave final approval for publication.

\section{Funding}

This work was financially supported by the National Natural Science Foundation of China for Distinguished Young Scholars (41825020) and General Program (31870461), the "Hundred Talent Program" of South China Botanical Garden at the Chinese Academy of Sciences (Y761031001), the "Young Top-notch Talent" in Pearl River talent plan of Guangdong Province (2019QN01L763), the Guangdong Basic and Applied Basic Research Foundation (2021A1515012147), and the China Scholarships Council

(No.202004910605).

\section{Availability of data and materials}

The datasets used and/or analyzed during the current study are available from the corresponding author on reasonable request.

\section{Declarations}

Ethics approval and consent to participate Not applicable.

Consent for publication

Not applicable.

\section{Competing interests}

The authors declare that they have no competing interests.

\section{Author details}

${ }^{1}$ Key Laboratory of Vegetation Restoration and Management of Degraded Ecosystems, South China Botanical Garden, Chinese Academy of Sciences, 
510650 Guangzhou, China. ${ }^{2}$ University of Chinese Academy of Sciences, 100049 Beijing, China. ${ }^{3}$ Department of Agroecology, Aarhus University, 8830 Tjele, Denmark. ${ }^{4} \mathrm{CSIRO}$ Oceans and Atmosphere, PMB 1, Victoria 3195 Aspendale, Australia. ${ }^{5}$ Aarhus University Centre for Circular Bioeconomy, Aarhus University, 8830 Tjele, Denmark. ${ }^{6}$ iCLIMATE Interdisciplinary Centre for Climate Change, Aarhus University, 4000 Roskilde, Denmark. ${ }^{7}$ Faculty of Life Science and Technology, Central South University of Forestry and Technology, 410004 Changsha, China. Institute of Applied Ecology, Chinese Academy of Sciences, 110016 Shenyang, China.

\section{Received: 5 April 2021 Accepted: 18 July 2021}

\section{Published online: 20 August 2021}

\section{References}

Amelung W, Kimble JM, Samson-Liebig S, Follett RF (2001a) Restoration of microbial residues in soils of the conservation reserve program. Soil Sci Soc Am J 65(6):1704-1709. https://doi.org/10.2136/sssaj2001.1704

Amelung W, Miltner A, Zhang X, Zech W (2001 b) Fate of microbial residues during litter decomposition as affected by minerals. Soil Sci 166(9):598-606. https://doi.org/10.1097/00010694-200109000-00003

Bossuyt H, Denef K, Six J, Frey SD, Merckx R, Paustian K (2001) Influence of microbial populations and residue quality on aggregate stability. Appl Soil Ecol 16(3):195-208. https://doi.org/10.1016/S0929-1393(00)00116-5

Chen C, Park T, Wang X, Piao S, Xu B, Chaturvedi RK, Fuchs R, Brovkin V, Ciais P, Fensholt R, Tømmervik H, Bala G, Zhu Z, Nemani RR, Myneni RB (2019) China and India lead in greening of the world through land-use management. Nat Sustain 2(2):122-129. https://doi.org/10.1038/s41893-019-0220-7

Chen C, Fang X, Xiang WH, Lei PF, Ouyang S, Kuzyakov Y (2020a) Soil-plant costimulation during forest vegetation restoration in a subtropical area of southern China. For Ecosyst 7:32. https://doi.org/10.1186/s40663-020-00242-3

Chen J, Elsgaard L, van Groenigen KJ, Olesen JE, Liang Z, Jiang Y, Lærke PE, Zhang Y, Luo Y, Hungate BA, Sinsabaugh RL, Jørgensen U (2020b) Soil carbon loss with warming: new evidence from carbon-degrading enzymes. Glob Chang Biol 26(4):1944-1952. https://doi.org/10.1111/gcb.14986

Cotrufo MF, Soong JL, Horton AJ, Campbell EE, Haddix Michelle L, Wall DH, Parton WJ (2015) Formation of soil organic matter via biochemical and physical pathways of litter mass loss. Nat Geosci 8(10):776-779. https://doi. org/10.1038/ngeo 2520

Dou X, Deng Q, Li M, Wang W, Zhang Q, Cheng X (2013) Reforestation of Pinus massoniana alters soil organic carbon and nitrogen dynamics in eroded soil in south China. Ecol Eng 52:154-160. https://doi.org/10.1016/j.ecoleng.2 012.12.099

Engelking B, Flessa H, Joergensen RG (2007) Shifts in amino sugar and ergosterol contents after addition of sucrose and cellulose to soil. Soil Biol Biochem 39(8):2111-2118. https://doi.org/10.1016/j.soilbio.2007.03.020

Farley KA, Kelly EF, Hofstede RGM (2004) Soil organic carbon and water retention following conversion of grasslands to pine plantations in the Ecuadoran Andes. Ecosystems 7(7):729-739. https://doi.org/10.1007/s1 0021-004-0047-5

Fomina M, Skorochod I (2020) Microbial interaction with clay minerals and its environmental and biotechnological implications. Minerals 10(10):861. https://doi.org/10.3390/min10100861

Frey SD, Elliott ET, Paustian K (1999) Bacterial and fungal abundance and biomass in conventional and no-tillage agroecosystems along two climatic gradients. Soil Biol Biochem 31(4):573-585. https://doi.org/10.1016/S0038-0717(98)001 61-8

Frostegård A, Bååth E (1996) The use of phospholipid fatty acid analysis to estimate bacterial and fungal biomass in soil. Biol Fertil Soils 22(1):59-65. https://doi.org/10.1007/bf00384433

Frostegård Å, Bååth E, Tunlio A (1993) Shifts in the structure of soil microbial communities in limed forests as revealed by phospholipid fatty acid analysis. Soil Biol Biochem 25(6):723-730. https://doi.org/10.1016/0038-0717(93)90113$\mathrm{P}$

Gu X, Fang X, Xiang W, Zeng Y, Zhang S, Lei P, Peng C, Kuzyakov Y (2019) Vegetation restoration stimulates soil carbon sequestration and stabilization in a subtropical area of southern China. CATENA 181:104098. https://doi. org/10.1016/j.catena.2019.104098

IUSS Working Group WRB (2007) World Reference Base for Soil Resources 2006: a framework for international classification, correlation and communication. http://www.ige.unicamp.br/pedologia/wsrr103e.pdf: 2006. Accessed 15 March 2021
Jastrow JD, Amonette JE, Bailey VL (2007) Mechanisms controlling soil carbon turnover and their potential application for enhancing carbon sequestration. Clim Change 80(1):5-23. https://doi.org/10.1007/s10584-006-9178-3

Kallenbach CM, Frey SD, Grandy AS (2016) Direct evidence for microbial-derived soil organic matter formation and its ecophysiological controls. Nat Commun 7(1):13630. https://doi.org/10.1038/ncomms13630

Kiem R, Kögel-Knabner I (2003) Contribution of lignin and polysaccharides to the refractory carbon pool in C-depleted arable soils. Soil Biol Biochem 35(1): 101-118. https://doi.org/10.1016/S0038-0717(02)00242-0

Koranda M, Kaiser C, Fuchslueger L, Kitzler B, Sessitsch A, Zechmeister-Boltenstern S, Richter A (2014) Fungal and bacterial utilization of organic substrates depends on substrate complexity and $N$ availability. FEMS Microbiol Ecol 87(1):142-152. https://doi.org/10.1111/1574-6941.12214

Kramer S, Marhan S, Ruess L, Armbruster W, Butenschoen O, Haslwimmer H, Kuzyakov Y, Pausch J, Scheunemann N, Schoene J, Schmalwasser A, Totsche KU, Walker F, Scheu S, Kandeler E (2012) Carbon flow into microbial and fungal biomass as a basis for the belowground food web of agroecosystems. Pedobiologia 55(2):111-119. https://doi.org/10.1016/.jpedobi.2011.12.001

Laganière J, Angers DA, Laganière J (2010) Carbon accumulation in agricultural soils after afforestation: a meta-analysis. Glob Chang Biol 16(1):439-453. https://doi.org/10.1111/j.1365-2486.2009.01930.x

Lal R (2003) Global potential of soil carbon sequestration to mitigate the greenhouse effect. CRC Crit Rev Plant Sci 22(2):151-184. https://doi.org/10.1 080/713610854

Liang C, Schimel JP, Jastrow JD (2017) The importance of anabolism in microbial control over soil carbon storage. Nat Microbiol 2:17105. https://doi.org/10.103 8/nmicrobiol.2017.105

Liang C, Amelung W, Lehmann J, Kästner M (2019) Quantitative assessment of microbial necromass contribution to soil organic matter. Glob Chang Biol 25(11):3578-3590. https://doi.org/10.1111/gcb.14781

Lu F, Hu H, Sun W, Zhu J, Liu G, Zhou W, Zhang Q, Shi P, Liu X, Wu X, Zhang L, Wei X, Dai L, Zhang K, Sun Y, Xue S, Zhang W, Xiong D, Deng L, Liu B, Zhou L, Zhang C, Zheng X, Cao J, Huang Y, He N, Zhou G, Bai Y, Xie Z, Tang Z, Wu B, Fang J, Liu G, Yu G (2018) Effects of national ecological restoration projects on carbon sequestration in China from 2001 to 2010. PNAS 115(16):40394044. https://doi.org/10.1073/pnas.1700294115

Lützow Mv, Kögel-Knabner I, Ekschmitt K, Matzner E, Guggenberger G, Marschner B, Flessa $\mathrm{H}$ (2006) Stabilization of organic matter in temperate soils: mechanisms and their relevance under different soil conditions - a review. Eur J Soil Sci 57(4):426-445. https://doi.org/10.1111/j.1365-2389.2006.00809.x

Ma T, Zhu S, Wang Z, Chen D, Dai G, Feng B, Su X, Hu H, Li K, Han W, Liang C, Bai $Y$, Feng $X$ (2018) Divergent accumulation of microbial necromass and plant lignin components in grassland soils. Nat Commun 9(1):3480. https:// doi.org/10.1038/s41467-018-05891-1

Malik AA, Chowdhury S, Schlager V, Oliver A, Puissant J, Vazquez PGM, Jehmlich $\mathrm{N}$, von Bergen M, Griffiths RI, Gleixner G (2016) Soil fungal: bacterial ratios are linked to altered carbon cycling. Front Microbiol 7(1247). https://doi.org/1 0.3389/fmicb.2016.01247

Nakas JP, Klein DA (1979) Decomposition of microbial cell components in a semi-arid grassland Soil. Appl Environ Microbiol 38(3):454-460. https://doi. org/10.1128/AEM.38.3.454-460.1979

Nave LE, Swanston CW, Mishra U, Nadelhoffer KJ (2013) Afforestation effects on soil carbon storage in the United States: a synthesis. Soil Sci Soc Am J 77(3): 1035-1047. https://doi.org/10.2136/sssaj2012.0236

Ni X, Liao S, Tan S, Peng Y, Wang D, Yue K, Wu F, Yang Y (2020) The vertical distribution and control of microbial necromass carbon in forest soils. Glob Ecol Biogeogr 29(10):1829-1839. https://doi.org/10.1111/geb.13159

Ouyang S, Xiang W, Wang X, Zeng Y, Lei P, Deng X, Peng C (2016) Significant effects of biodiversity on forest biomass during the succession of subtropical forest in south China. For Ecol Manage 372:291-302. https://doi.org/10.1016/ j.foreco.2016.04.020

Rinnan R, Bååth E (2009) Differential utilization of carbon substrates by bacteria and fungi in tundra soil. Appl Environ Microbiol 75(11):3611-3620. https:// doi.org/10.1128/AEM.02865-08

Sauer TJ, James DE, Cambardella CA, Hernandez-Ramirez G (2012) Soil properties following reforestation or afforestation of marginal cropland. Plant Soil 360(1):375-390. https://doi.org/10.1007/s11104-012-1258-8

Shao S, Zhao Y, Zhang W, Hu G, Xie H, Yan J, Han S, He H, Zhang X (2017) Linkage of microbial residue dynamics with soil organic carbon accumulation during subtropical forest succession. Soil Biol Biochem 114: 114-120. https://doi.org/10.1016/j.soilbio.2017.07.007 
Shao P, Liang C, Lynch L, Xie H, Bao X (2019) Reforestation accelerates soil organic carbon accumulation: evidence from microbial biomarkers. Soil Bio Biochem 131:182-190. https://doi.org/10.1016/j.soilbio.2019.01.012

Six J, Conant RT, Paul EA, Paustian K (2002) Stabilization mechanisms of soil organic matter: implications for C-saturation of soils. Plant Soil 241(2):155176. https://doi.org/10.1023/A:1016125726789

Six J, Frey SD, Thiet RK, Batten KM (2006) Bacterial and fungal contributions to carbon sequestration in agroecosystems. Soil Sci Soc Am J 70(2):555-569. https://doi.org/10.2136/sssaj2004.0347

Strickland MS, Rousk J (2010) Considering fungal:bacterial dominance in soils Methods, controls, and ecosystem implications. Soil Biol Biochem 42(9):13851395. https://doi.org/10.1016/j.soilbio.2010.05.007

Sun L, He L, Wang G, Jing H, Liu G (2019) Natural vegetation restoration of Liaodong oak (Quercus liaotungensis Koidz.) forests rapidly increased the content and ratio of inert carbon in soil macroaggregates. J Arid Land 11(6): 928-938. https://doi.org/10.1007/s40333-019-0004-y

Vestal JR, White DC (1989) Lipid analysis in microbial ecology: quantitative approaches to the study of microbial communities. Bioscience 39(8):535-541. https://doi.org/10.2307/1310976

Veum KS, Lorenz T, Kremer RJ (2019) Phospholipid fatty acid profiles of soils under variable handling and storage conditions. Agron J 111(3):1090-1096. https://doi.org/10.2134/agronj2018.09.0628

Wang F, Ding Y, Sayer EJ, Li Q, Zou B, Mo Q, Li Y, Lu X, Tang J, Zhu W, Li Z (2017) Tropical forest restoration: fast resilience of plant biomass contrasts with slow recovery of stable soil C stocks. Funct Ecol 31(12):2344-2355. https://doi. org/10.1111/1365-2435.12925

Wieder WR, Hartman MD, Sulman BN, Wang Y-P, Koven CD, Bonan GB (2018) Carbon cycle confidence and uncertainty: exploring variation among soil biogeochemical models. Glob Chang Biol 24(4):1563-1579. https://doi.org/1 $0.1111 /$ gcb.13979

Xiong X, Zhang H, Deng Q, Hui D, Chu G, Meng Z, Zhou G, Zhang D (2020) Soil organic carbon turnover following forest restoration in south China: evidence from stable carbon isotopes. Forest Ecol Manag 462:117988. https://doi.org/10.1016/j.foreco.2020.117988

Xu Y, Xu Z, Cai Z, Reverchon F (2013) Review of denitrification in tropical and subtropical soils of terrestrial ecosystems. J Soils Sediments 13(4):699-710. https://doi.org/10.1007/s11368-013-0650-1

Xu Y, Vinas M, Alsarrag A, Su L, Pfohl K, Rohlfs M, Schäfer W, Chen W, Karlovsky P (2019) Bis-naphthopyrone pigments protect filamentous ascomycetes from a wide range of predators. Nat Commun 10(1):3579-3579. https://doi.org/10.1 038/s41467-019-11377-5

Yang L, Lyu M, Li X, Xiong X, Lin W, Yang Y, Xie J (2020) Decline in the contribution of microbial residues to soil organic carbon along a subtropical elevation gradient. Sci Total Environ 749:141583. https://doi.org/10.1016/j. scitotenv.2020.141583

Yu M, Wang Y, Jiang J, Wang C, Zhou G, Yan J (2019) Soil organic carbon stabilization in the three subtropical forests: importance of clay and metal Oxides. J Geophys Res Biogeosci 124(10):2976-2990. https://doi.org/10.1029/2 018jg004995

Zelles $L$ (1997) Phospholipid fatty acid profiles in selected members of soil microbial communities. Chemosphere 35(1):275-294. https://doi.org/10.1016/ S0045-6535(97)00155-0

Zelles L (1999) Fatty acid patterns of phospholipids and lipopolysaccharides in the characterisation of microbial communities in soil: a review. Biol Fertil Soils 29(2):111-129. https://doi.org/10.1007/s003740050533

Zhang X, Amelung W (1996) Gas chromatographic determination of muramic acid, glucosamine, mannosamine, and galactosamine in soils. Soil Biol Biochem 28(9):1201-1206. https://doi.org/10.1016/0038-0717(96)00117-4

Zhang X, Amelung W, Yuan Y, Zech W (1998) Amino sugar signature of particlesize fractions in soils of the native prairie as affected by climate. Soil Sci 163 : 220-229. https://doi.org/10.1097/00010694-199803000-00007

Zhang Y, Zhang J, Meng T, Zhu T, Müller C, Cai Z (2013) Heterotrophic nitrification is the predominant $\mathrm{NO}_{3}^{-}$production pathway in acid coniferous forest soil in subtropical China. Biol Fertil Soils 49(7):955-957. https://doi. org/10.1007/s00374-012-0772-4

Zhang H, Deng Q, Hui D, Wu J, Xiong X, Zhao J, Zhao M, Chu G, Zhou G, Zhang D (2019) Recovery in soil carbon stock but reduction in carbon stabilization after 56-year forest restoration in degraded tropical lands. Forest Ecol Manag 441:1-8. https://doi.org/10.1016/j.foreco.2019.03.037
Zhou G, Liu S, Li Z, Zhang D, Tang X, Zhou C, Yan J, Mo J (2006) Old-growth forests can accumulate carbon in soils. Science 314(5804):1417-1417. https:// doi.org/10.1126/science.1130168

Zhou G, Xu S, Ciais P, Manzoni S, Fang J, Yu G, Tang X, Zhou P, Wang W, Yan J, Wang G, Ma K, Li S, Du S, Han S, Ma Y, Zhang D, Liu J, Liu S, Chen X (2019) Climate and litter $\mathrm{C} / \mathrm{N}$ ratio constrain soil organic carbon accumulation. Natl Sci Rev 6:746-757. https://doi.org/10.1093/nsr/nwz045

Zhu WJ, Xiang WH, Pan Q, Zeng YL, Ouyang S, Lei PF, Deng XW, Fang X, Peng $\mathrm{CH}$ (2016) Spatial and seasonal variations of leaf area index (LAI) in subtropical secondary forests related to floristic composition and stand characters. Biogeosciences 13(12):3819-3831. https://doi.org/10.5194/bg-13-3 819-2016

\section{Submit your manuscript to a SpringerOpen ${ }^{\circ}$ journal and benefit from:}

- Convenient online submission

- Rigorous peer review

- Open access: articles freely available online

- High visibility within the field

- Retaining the copyright to your article

Submit your next manuscript at $\boldsymbol{\nabla}$ springeropen.com 